\title{
Going up or going down? Occupational mobility of skilled migrants in Australia
}

\author{
Susan Ressia Griffith University, Australia \\ Glenda Strachan Griffith University, Australia \\ Janis Bailey Griffith University, Australia
}

Skilled migration programs are now widespread among western settler societies, but little is known about the recent outcomes of skilled migrants. Using a feminist framework and qualitative interviews of 22 migrants, this article sheds light on the job-seeking experiences of professional skilled migrants in Australia, who are from non-English speaking backgrounds. The article reveals that many are unable to find commensurate employment post-arrival. They experience downward occupational mobility; that is they find jobs that are lower in skill level compared to the job held pre-migration. The range of job-seeking strategies is examined to determine whether migrants can improve occupational outcomes, revealing differences between the mobility of women and men. Job-seeking for women is more complex due to the gendering effects of family responsibility, making their job search more difficult. The research further highlights the underutilisation of human capital, which is in need of addressing for skilled migrants, and the wider economy.

Keywords: Australia, downward occupational mobility, employment, job search strategies, migrants

\footnotetext{
Key points

1 Migrants expect that migration will lead to better employment outcomes and increased economic opportunity.

2 Migrant women and men have different experiences of job-seeking post-migration.

3 The mobility trajectories for women are more difficult due to gendering effects.

4 T. 1 udy reveals the underutilisation of human capital in the Australian labour market.

5 The research presents issues for consideration by government, organisations and migrant support networks around immigration policy and the outcomes of independent skilled migrants.
}

Correspondence: Dr Susan Ressia, Department of Employment Relations and Human Resources, Griffith Business School, Griffith University, Nathan Campus, Brisbane, Qld 4111, Australia; e-mail: s.ressia@griffith.edu.au

Accepted for publication 25 June 2016.

\begin{tabular}{|c|c|c|c|l|l|}
\hline \multirow{2}{*}{$\mathcal{N}$} & A P H R & 12121 & \multirow{2}{*}{ WILEY } & Dispatch: 1.8.16 & CE: Saravanan S \\
\cline { 2 - 3 } \cline { 5 - 6 } & Journal Code & Manuscript No. & & No. of pages: 22 & PE: Bhagyalakshmi \\
\hline
\end{tabular}


Migrants are increasingly entering the major settler societies of Australia, Canada, New Zealand as well as the United Kingdom through skilled migration programs. Based on a human capital approach, these programs use points systems to select immigrants according to a mix of skill, education and language levels, age and occupational experience (Anderson 2010; Boucher and Cerna 2014). The points system is a Canadian innovation, first introduced in 1962 and adopted by Australia in 1973 (Papademetriou and Sumption 2011; Walsh 2008). These points-based skilled migration programs were originally offered in conjunction with existing family reunion and humanitarian immigration programs. More recently, greater emphasis has been placed on using such programs to fill skill gaps in local labour markets, and therefore immigration flows have increased in the skill-based streams. Canada and Australia are often considered exemplars of such policies (Boucher and Cerna 2014). Australia led the way in 1979 with a system focusing on the economic attributes of migrants (Walsh 2008) and in 1996 introduced two new programs, the independent skilled and the employer-nominated programs (Wright 2012). These more recent programs require applicants to achieve a set number of points based on their human capital; the employer-nominated program enables pre-arranged employment for a migrant on arrival. Many countries, including Denmark, Finland, France, Germany, Iceland, Italy, Japan, the Netherlands, Norway, New Zealand, Malaysia, Singapore, Hong Kong and the United States, have since modelled their immigration policies on these programs (Papademetriou and Sumption 2011; Walsh 2008). The United Kingdom introduced its own points system modelled on the Australian system (Anderson 2010; Clarke and Skuterud 2014) in June 2008. The UK system was modified in 2011 to provide two schemes: the Tier 1 Exceptional Talent (highly skilled) scheme and the Tier 2 Skilled scheme (Kofman 2013).

While these programs are achieving migrant intake levels to support the economic objectives of the receiving countries, and counteract declining birthrates and ageing populations (Phan et al. 2015), it appears that employment outcomes for skilled migrants are unsatisfactory (Birrell and Healy 2008; Rynderman and Flynn 2014) - migrants are not finding good employment outcomes post-migration (Bertone 2009; Ho and Alcorso 2004; Misko 2012); that are equal in occupational standing to the job held in their home country. However, we know little about the job search processes skilled independent migrants and their partners undertake once arrived, or how they adapt to their new home country. Specifically, it would be useful to know what constrains their choices when seeking work (Fossland 2013), and how downward occupational mobility (Ho 2006; Ho and Alcorso 2004; Vianello 2014) occurs when skills, qualifications and knowledge are not adequately recognised and/or are undervalued (Bartram 2010; Shan 2013). Thus, there is a pressing need to examine and understand how skilled migrants respond when faced with unemployment and other challenges. This includes how gender and race 'play out in the context of migration' during the negotiation of family roles (Kofman 2013, 121; Phan et al. 2015).

The issue of gender and migration is important. Female migration is increasing globally, and the number of primary female applicants now equals or exceeds male ones 
(Docquier, Lowell, and Marfouk 2009). Because national policies emphasise skilled migration, many more women are entering Australia as independent skilled migrants with high-level skills, qualifications and experience (Syed and Murray 2009). There are also many highly qualified migrant women arriving as spouses of male applicants (Kofman and Raghuram 2006). However, to date the job-seeking experiences and outcomes of skilled migrant women have been less visible than those of men (Kofman 2013; Shinozaki 2014). This paper contributes a more nuanced understanding of the experiences of the complex issues that women and male migrant job-seekers face, when searching for work in the Australian labour market.

Drawing on the occupational mobility (Lno and Ferrie 2003) and migrant mobility literatures (McAllister 1995), and considers 2 ler and race categories within the labour market (Browne and Misra 2003), this article explores the lived experiences of 22 skilled migrants from non-English speaking backgrounds (NESB) who arrived in Brisbane, Australia between 2004 and 2008. It aims to fill a significant gap in the literature on skilled migrants and employment by analysing the job-seeking experiences of such migrants from varied ethnic minority and racial backgrounds. The research focuses on the experiences of primary applicants, who are migrants to whom the approval to immigrate was granted (Chiswick, Lee and Miller 2005), and of skilled migrants who have arrived via a spouse (secondary applicant) or humanitarian visa. This article addresses three questions: 1) Do skilled NESB migrants achieve good employment outcomes post-migration, and if not, what strategies do they use to overcome downward occupational mobility? 2) What are the experiences and outcomes for migrating partners who have equally high skill levels? 3) How do gender and family roles impact job search outcomes?

\section{Occupational mobility and migrant mobility}

The literature on skilled migrant employment hints at considerable underuse of skills; that is, migrants often cannot find jobs at their skill levels. This leads to downward occupational mobility. In the case of skilled migrants, the act of migration creates the initial change in social standing as a result of their 'migrant mobility' (McAllister 1995). Occupational mobility is defined in terms of class systems where a person belonging to a particular class, such as low, middle or upper, is determined by their education and occupation, and by other factors such as cultural and social interests (Jackson 2009). In the case of migration, class becomes disrupted, as skilled migrants voluntarily cut ties to their former social class system. Left with their human capital (education and skills), which they may find difficult to transfer (Bertone 2009; Birrell 2009; Birrell and Rapson 2005; Chiswick, Lee and Miller 2005), they face a change in social class as a result of their 'new migrant' status (Ressia 2014). Furthermore, they unexpectedly face perceived discrimination in local employment processes of which they may have little knowledge (Birrell and Rapson 2005; Rynderman and Flynn 2014), and may find themselves occupying jobs which are at a lower occupational level (if they do find work). Thus, skilled migrants - despite their educational and professional achievements - suffer as a result of 
their move, and experience 'downward occupational mobility' (Ho 2006; Ho and Alcorso 2004; Vianello 2014), becoming relegated to lower level occupations, and/or experiencing unemployment leading to 'brain waste' (Papademetriou and Sumption 2011).

Occupational mobility is a concept widely studied in the economic and sociology literatures. The economic literature uses the overarching concept of 'labour mobility', encompassing both occupational and geographic mobility, describing (respectively) the changes that occur across a set of jobs for an individual, and changes that occur across space (Long and Ferrie 2003). The mobile employee's intention is that improved employment and economic benefits will occur as a result of these moves (Groutsis and Arnold 2012; Hawthorne 2005; Iredale 2001). The sociology literature focuses on occupational mobility, deriving from Weber's concept of social mobility that occurs within and between class structures (Smith 2007), where social class is measured through an individual's occupation ( literature has investigated on s, with many studies of occupational mobility tracking intergenerational employment outcomes between white, Anglo fathers and their sons (Goldthorpe, Payne, and Llewellyn 1978; Long and Ferrie 2013; Sørensen 1991). More recently, however, research has considered women (Goldthorpe and Payne 1986), as well as the occupations of both mother and father in relation to the occupational outcomes of children (Glaesser and Cooper 2014; Jackson 2009). This literature recognises that certain characteristics such as 'family background, parent's education, occupation and income, race and gender... play a key role in shaping future trajectories of social position and status' (Adkins and Vaisey 2009, 100).

'Migrant mobility' (McAllister 1995, 447) 'applies solely to immigrants ... who have worked prior to migration' and compares the differences between a migrant's occupation achieved in their home country and the first job held in their new country (McAllister 1995). Migrants expect that the act of migration will lead to better employment outcomes, and thus increased economic opportunity (Dean and Manzoni 2012; Groutsis and Arnold 2012; Iredale 2001). The limited research undertaken to date reveals the reverse; that is, employment and economic opportunities decline (Simón, Ramos, and Sanromá 2014; Vianello 2014). Even where improvement in occupational status occurs over time, the level eventually achieved may never make up for the initial loss (Simón, Ramos, and Sanromá 2014). However, there is little recent qualitative research examining the labour market experiences of skilled migrants (Syed and Murray 2009). Quantitative (survey) research in various international labour markets, including Germany (Bauer and Zimmermann 1999), Spain (see Simón, Ramos, and Sanromá 2014), Sweden (Rooth and Ekberg 2006) and the United States (Akresh 2008) confirm that migrants experience downward occupational mobility, as their first jobs are typically lower in status than their former positions in their home countries (Akresh 2008; Chiswick, Lee and Miller 2003; Ho 2006; Ho and Alcorso 2004; Rooth and Ekberg 2006). Bauer and Zimmermann $(1999,15)$ found that highly skilled migrants tend to suffer more than others, due to the 'imperfect transferability of skills between different countries'. Employment outcomes for migrants in Australia have recently been captured through the Continuous survey of Australia's migrants (CSAM; 


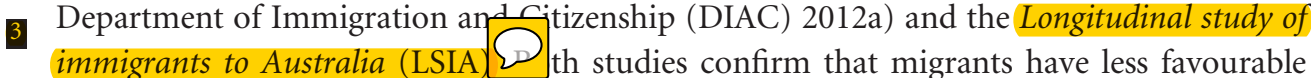
labour market outcomes than similarly qualified local-born employees, and experience lower wages (see Mahuteau and Junankar 2008).

Two theories of migrant mobility may explain the experience of downward occupational mobility: the 'assimilation model' and 'segmented assimilation theory' (Simón, Ramos, and Sanromá 2014). The assimilation model holds that migrants initially may be able to gain employment only in lower level occupations but, over time, their occupational status improves as they build upon their human capital. Chiswick, Lee and Miller $(2005,335)$ refer to this process as the 'U-shaped pattern' of migration, meaning that high skilled migrants' skills are not perfectly transferable, and so they will experience a 'decline in occupational status from the last job in the origin [country] to the first job in the destination [country]'. The assimilation model suggests that skilled migrants need to undertake additional training, improve their language skills, obtain workplace experience and develop career networks to enable them to achieve better career outcomes (Chiswick, Lee and Miller 2005). In other words, it is essentially a 'deficit' model; where the cause is located in the individual, while the surrounding social structure is ignored, so the

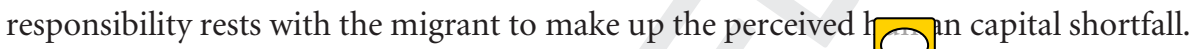

Segmented assimilation theory, in contrast, examines on ants who experience a more permanent form of occupational downgrading, that is, those who find employment only in lower skilled jobs. This theory suggests that this downgrading prevents migrants from improving their occupational outcomes (Simón, Ramos, and Sanromá 2014, 224225), which can be subject to broader macro/national and meso/organisational factors and impact upon the employment chances of migrants. For example, limited policy at the national level in areas such as anti-discrimination and managing diversity programs, and indirect forms of discrimination at the organisational level, can work together to exclude skilled migrants from achieving better occupational outcomes in the labour market (Syed 2008; Syed and Murray 2009). The empirical literature shows that migrants experience both a dislocation and a disruption in achieving employment in their career of choice (Anthias 2012; McDowell 2008). As their social and occupational mobility trends downwards, their occupational identity fractures, their self-confidence suffers, and they may experience physical and emotional impacts (Remennick 2005).

\section{The migrant job search in Australia}

As noted above, economic pressures in the latter part of the twentieth century saw a shift in Australian immigration policy to a focus on increasing skilled migrant intakes. To fill labour shortfalls, two general skilled migration (GSM) categories were made available in 1996: independent and employer-nominated (sponsored) migration. Currently, 68\% of migrants enter via the skilled program (Department of Immigration and Border Protection (DIBP) 2015a). It was envisaged that this policy change would have a positive effect in reducing the unemployment rate of NESB migrants which at that time was $12 \%$ 
compared to $7.9 \%$ for the Australian-born (ABS 1996). Improvements were reported, as government statistics (DIAC 2012a) showed that in 2010 the employment participation rates of primary applicants within the independent and business employer-nominated and the regional sponsored schemes were in excess of 95\%. However, this does not tell us about the type of job gained, nor disaggregate English speaking and NESB migrants, or women and men.

Studies (Ho 2006; Rynderman and Flynn 2014) confirm that initial employment outcomes for women and male independent skilled migrants are problematic, and the challenges they face are many and varied. In addition to the challenges highlighted, issues include their lack of familiarity with the Australian economy, and lack contextual knowledge about local job search processes (Bertone 2000; Chiswick, Lee and Miller 2003; Rynderman and Flynn 2014). They may also lack knowledge about selling their skills effectively (Ressia 2014). Another challenge is racial discrimination by employers, evident in a study on migrant employment in Australia by Booth, Leigh and Varganova (2010). The authors found that after submitting a range of fictitious job applications to employers, the call-back rate for applications containing Chinese and middle eastern names was 'significantly lower than for Anglo and Italian names' (Booth, Leigh and Varganova 2010, 9). They $(2010,13)$ also found that Chinese job-seekers in Brisbane would need to submit on average, a total of ' 57 per cent more applications' in order to achieve the same number of interviews as an applicant of Anglo decent. Hence, migrants are not only disadvantaged by their lack of knowledge about labour market processes, they face discrimination at the point of applying for a job, and lose out on valuable feedback that they could achieve through this process.

To further complicate the migrant job search, women and men appear to have different experiences of job-seeking post-migration. This can be attributed to the operation of gender norms and differing structural constraints around employment. For example, a man's identity is strongly connected to highly gendered economic breadwinner norms (Campbell, Whitehouse and Baxter 2009; Hibbins 2005), and migrant men, in the process of seeking employment, may often struggle to reach an occupational status and economic identity equivalent to their previous status and identity. They then must accept work in lower skilled jobs unrelated to their profession, simply to survive (Raghuram 2008). Migrant women can also face particular difficulties in finding appropriate work, which can be the result of social structures such as the division of labour within households, thus emphasising the gendered role of the male breadwinner (Campbell, Whitehouse and Baxter 2009; Phan et al. 2015). The provision of economic security for the family can be a major reason women need to gain employment and, like men, they are willing to undertake less skilled work (Colic-Peisker and Tilbury 2007). Thus, many migrant women face dual imperatives: the impetus to partake in the public sphere to improve their own and their family's economic security (Alcorso 1991; Colic-Peisker and Tilbury 2007; Iredale 2005, 2001; Ressia 2014), while managing family responsibilities in the home. Gendered family roles often place additional burdens on women when seeking work (Kofman 2013) as do social and cultural expectations (Cooke 2007). These may include 
lack of spousal support, limited access to appropriate childcare and other support systems, and loss of established networks of family and friends (Ho and Alcorso 2004; Kõu et al. 2015; Shinozaki 2014). For both women and men migrant job-seekers the picture is quite complex, and both sexes face economic disadvantage and lower class status.

\section{Research methods}

This research explored the lived experiences and outcomes of recently arrived NESB skilled migrants seeking employment within the Brisbane urban region of southeast Queensland, Australia. To understand the job search experiences and strategies of participants, it was clear from the outset that qualitative techniques were required, and would add to the existing research developed from quantitative data sets. The interview is an important means of gathering information that provide insights into, develops understanding of, and voices the individual's experiences (Fontana and Frey 2000). A semi-structured interview process was used, and a narrative analysis technique adopted, to focus on the specific stories of individuals and preserve the integrity of personal biographies and events contained within them (Riessman 2002, cited in Chambliss and Schutt 2006).

Situating the research within an occupational mobility and migrant mobility framework, and highlighting outcomes due to gender and race differences (Browne and Misra 2003), interviews were conducted with NESB skilled migrants (17 women and 5 men) from 16 countries. They were sourced via government bodies and community-based organisations which assisted in advertising for participants. The participants were skilled, with high levels of education, and all had good English language ability (see tables 1 and 2). Participants had been living in Australia for between 6 months and 5 years prior to being interviewed, with the majority having arrived within the previous 1-3 years. Each participant was interviewed twice, 12 months apart (phase 1 and phase 2), to explore their experiences and elucidate the 'journey' that each had taken. Each interview lasted 30-90 minutes, and was tape-recorded and transcribed. The interview questions featured in phase 1 reflected issues that emerged from the literature, where the themes explored included individuals' reasons for migrating; initial employment expectations; difficulties and barriers faced in job-seeking as well as their spouse or partner's experiences of seeking work. Phase 2 interviews analysed how their job search had progressed over the preceding 12-month period. This enabled us to learn more about the impact of their job-seeking journey, whether migrants were still happy to have migrated to Australia, and what strategies they were using to continue their job search if they had not found commensurate employment.

The transcripts were analysed using NVivo 9 software (QSR International Pty Ltd 2010) beginning with open coding of each transcribed interview. The transcribed interviews were also sent to each participant to ensure that their stories had been represented accurately and truthfully. Themes from the transcript data were identified from a review of the literature, in addition to new themes that emerged from participants' own stories (Böhm 2004). The analysis drew on a model devised by Charmaz (2000) which emphasised a reflexive approach throughout the research process. Axial-coding processes 


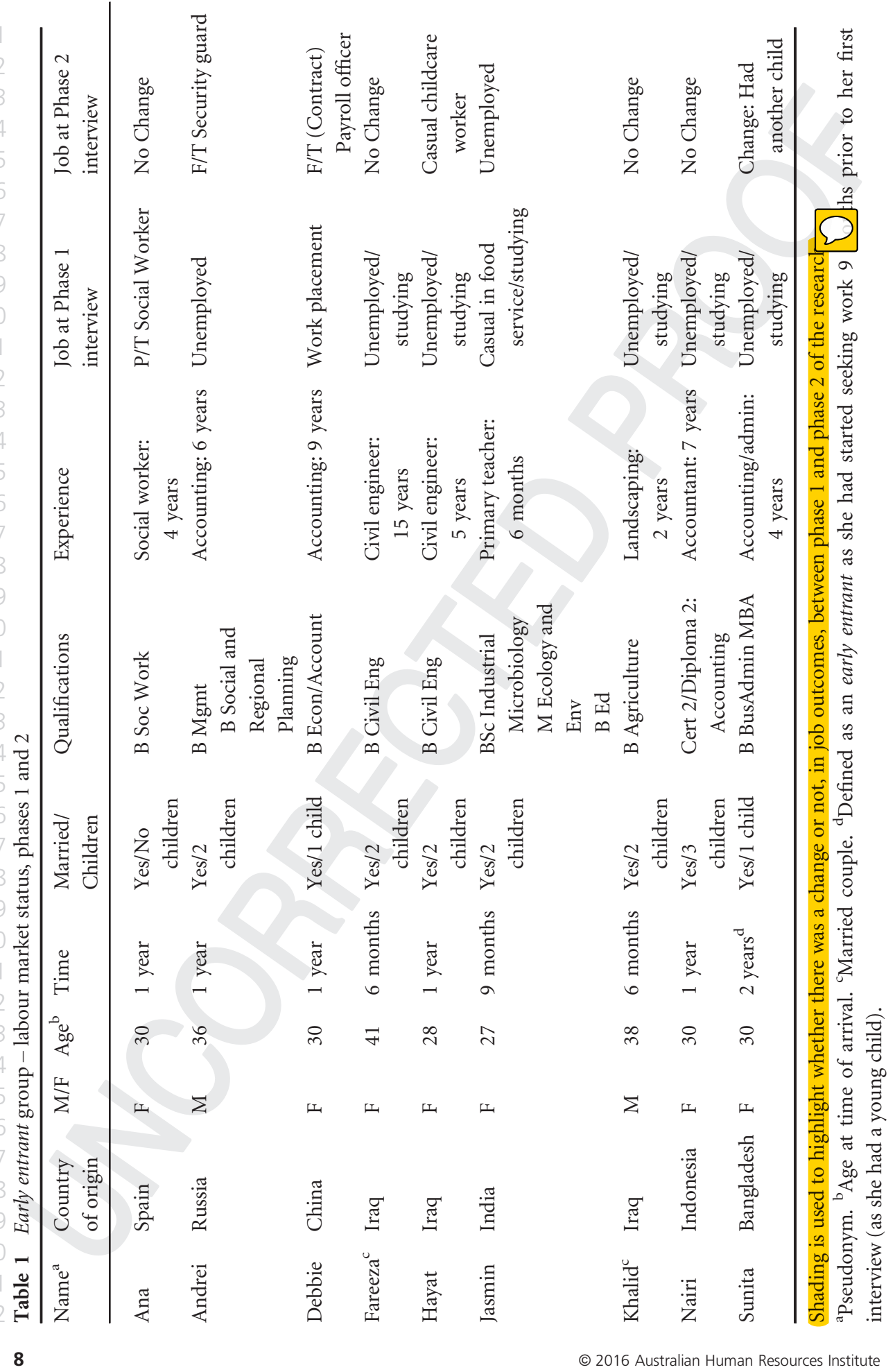


Susan Ressia, Glenda Strachan and Janis Bailey

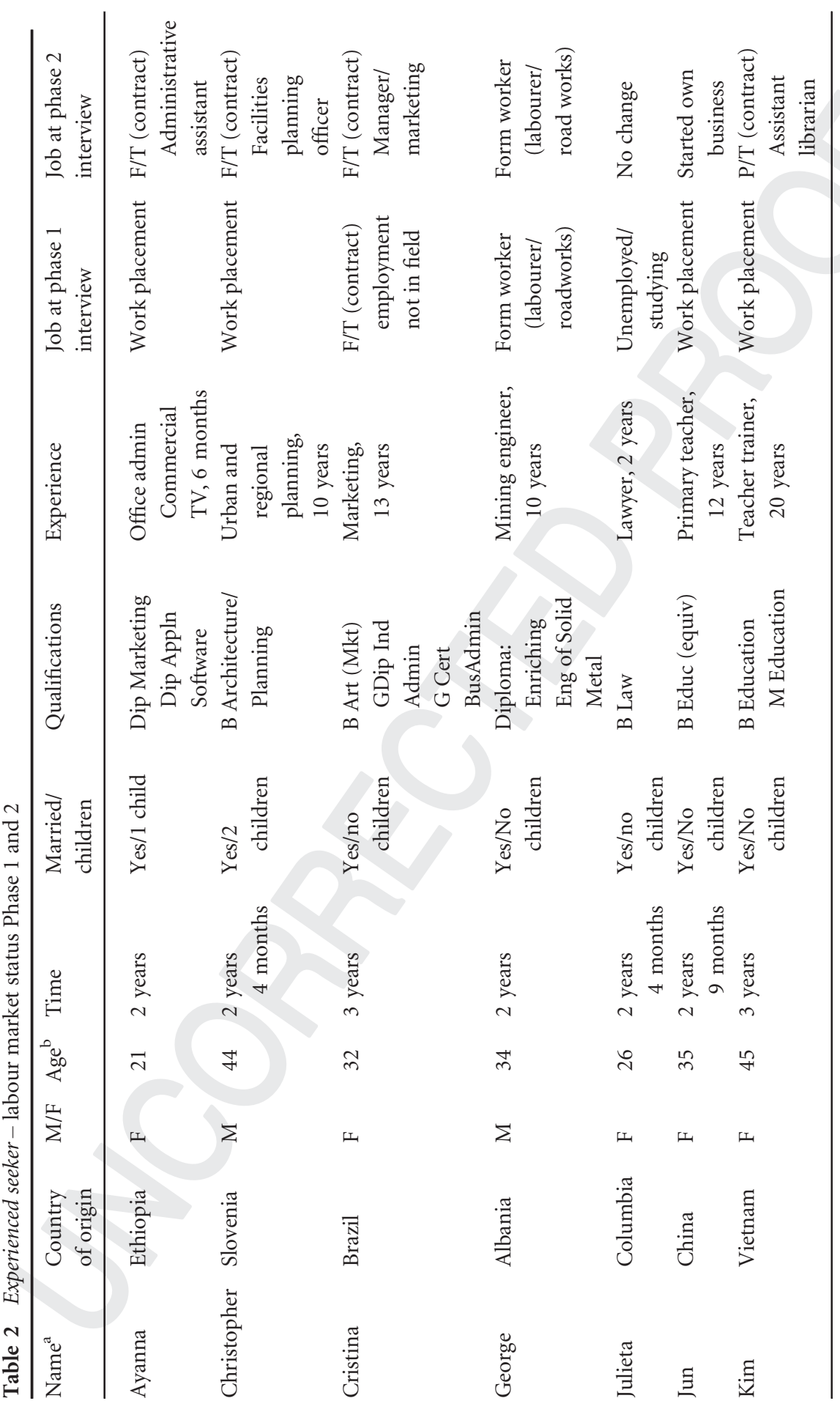


Asia Pacific Journal of Human Resources ••

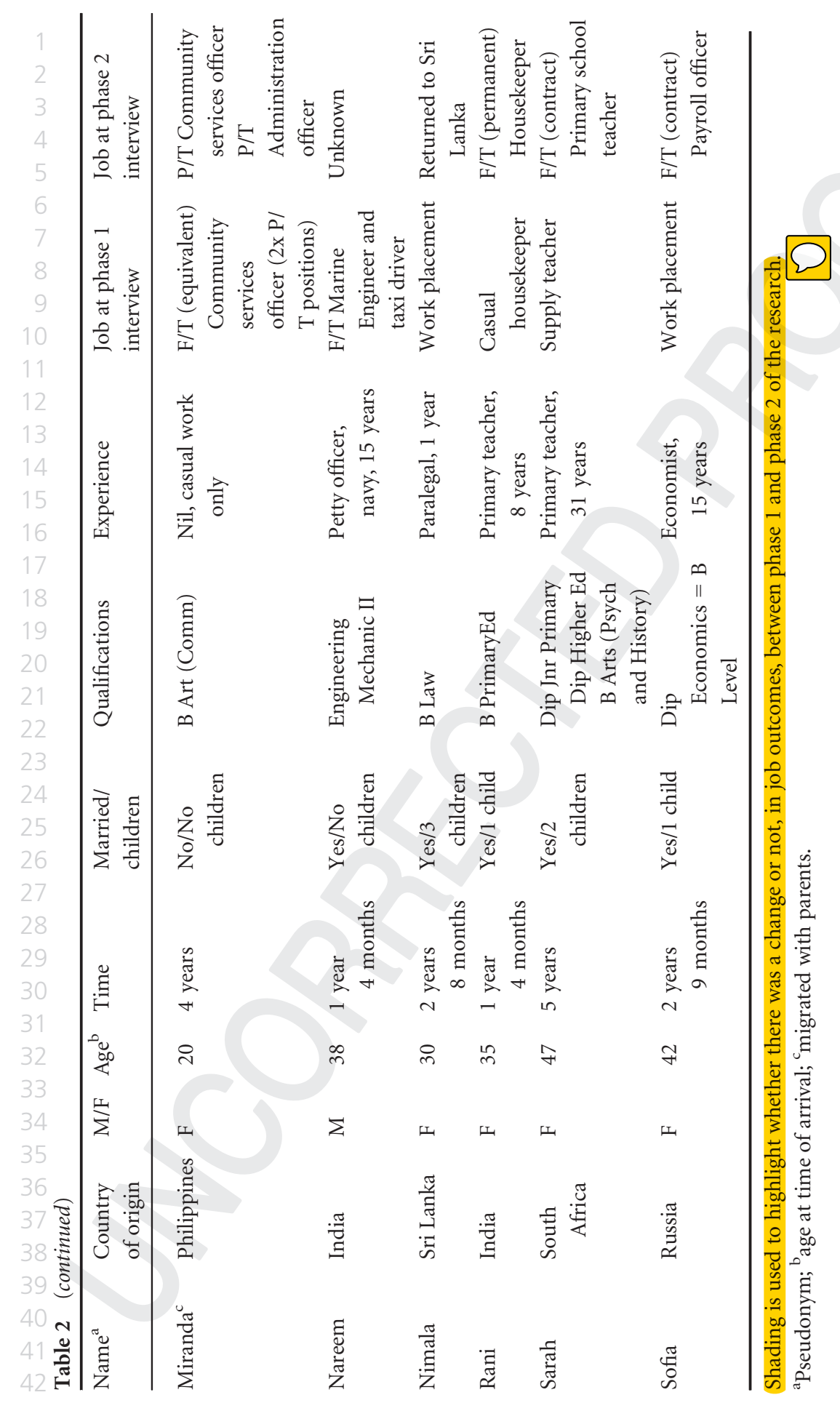


were undertaken during the middle and later stages of the analysis (Böhm 2004). Selective coding and theory development were undertaken by integrating all the collected information, including the coded interview data, diary notes and memos from the analysed stories (Böhm 2004).

Demographic details of each participant, including their qualifications and employment experience prior to migrating to Australia, are outlined in Table 1 (the early entrant group who had been seeking work for a period of 1 year or less) and Table 2 (the experienced job-seeker group who had been in Australia for longer than 12 months). The majority of job-seekers in the latter group had been looking for work for between 2 and 3 years. The tables also provide information on labour market status, including details of the type of job (if any) the participants had at the time of the two interviews.

\section{Experiences of downward occupational mobility}

This group of NESB skilled migrants did not find the employment that they expected prior to migration. Many believed they would achieve good employment outcomes as they had the skills and attributes required to achieve entry into Australia under what seemed to them a fairly rigorous set of standards. As their occupation had been listed on the former Migration Occupations in Demand List (MODL), or the Skilled Occupations List (SOL) (for examples see DIBP 2015b), they supposed that their job search would be relatively easy. Participants also expected that by finding good employment - in most cases relatively quickly - they would be able to develop their professional careers.

At the time of the phase 1 interviews, two-thirds of the early entrant participants were unemployed (see Table 1). Of the remaining participants in this group, one was undertaking a work placement and two were in jobs not equal to the occupation held premigration. Four of the participants were employed but all had experienced downward occupational mobility. For three participants their new work was insecure as well as lower in status, with participants employed on a contract, casual (temporary) or part-time basis. Outcomes were much better for the experienced seekers. In phase 1, only one participant, Julieta, was unemployed (see Table 2). Five had found work placements and 7 were employed, although not in jobs commensurate with their professional qualifications. Many of the participants had engaged or were currently involved in work-placement programs, often after internet searches, or hearing about them from a friend or a community-based organisation. Nevertheless, the majority of participants had experienced downward occupational mobility. However, by phase 2 there was a noticeable shift in employment outcomes for those who had participated in a work-placement program developed by a local authority, and a few had found a route back to their profession - for example, Sarah was a teacher (although on contract rather than permanently employed).

\section{Counteracting downward occupational mobility: job-seeking strategies}

Participants used a range of strategies in their search for work, confirming research which suggests migrants try to build upon their human capital by developing their own 'career 
self-management strategies' (Fang, Novicevic, and Zikic 2009, 474). The migrants in this research used a range of strategies (see Table 3), including: volunteering; finding any job to bring in income and gain local experience; internet searches; assistance from recruitment companies; work placements; contact with community-based organisations, and utilising social networks. Further education is noted as a strategy widely used by migrants seeking employment (Fang, Novicevic and Zikic 2009). Consistent with this finding, many participants indicated that they were pursuing further study as a way to improve employment outcomes in four (related) ways: to improve language skills; to assist them in meeting professional registration requirements; to gain an Australian qualification; and to change career. For some, like Ana, Cristina, Fareeza and Khalid, English language courses were viewed as essential as they perceived that inadequate language skills hampered their quest for employment. Teachers Jasmin, Jun and Rani, were particularly keen to gain registration, and undertook further study to achieve this outcome. Some participants decided that further study was needed to achieve an Australian qualification in a similar or related field to their professional degree in order to improve contextual knowledge of local practices, and to increase the likelihood of finding work. Miranda and George both said that they saw importance in forming new connections, and viewed further study as a mechanism for this. Study was used to change career (for example, Hayat and Rani who chose to study childcare). In all of the cases above, we observed that the changes in occupational status led each skilled migrant to experience downward occupational mobility.

Of course, while skilled migrants concentrate on their career self-management strategies, they still need to find work to exist. For instance, Andrei expressed the importance of his first job as a means to provide financial resources to the family: 'this job [is] not actually what I [am] supposed to do, but it gives money, and money to pay bills, rent ... all the necessary stuff. This work, while unsatisfactory from a career perspective, may have some benefits: Andrei found that the job gave him the opportunity to improve his English language skills, and provided him with valuable local work experience. Andrei's experience could potentially be explained by the assimilation model of occupational mobility. While obtaining a job in a lower level occupation (Chiswick, Lee and Miller 2005), he is undertaking further study to help him move upward in occupational status, and reclaim his occupational identity. Jasmin too was concerned with making enough money for the family to survive, similar to the findings of Raghuram (2008), but said her catering job was an opportunity to form networks by making friends, and to gain new knowledge about Australian workplaces. This became part of her overall strategy, as she was intent on providing the means to fund additional studies to meet professional requirements, and increase her occupational mobility while considering the care of her children around school hours.

\section{Decision-making around employment and family}

The data show that the decline in occupational status affects both women and men, but in different ways. Decision-making and job-seeking strategies are shaped by traditional 
Susan Ressia, Glenda Strachan and Janis Bailey

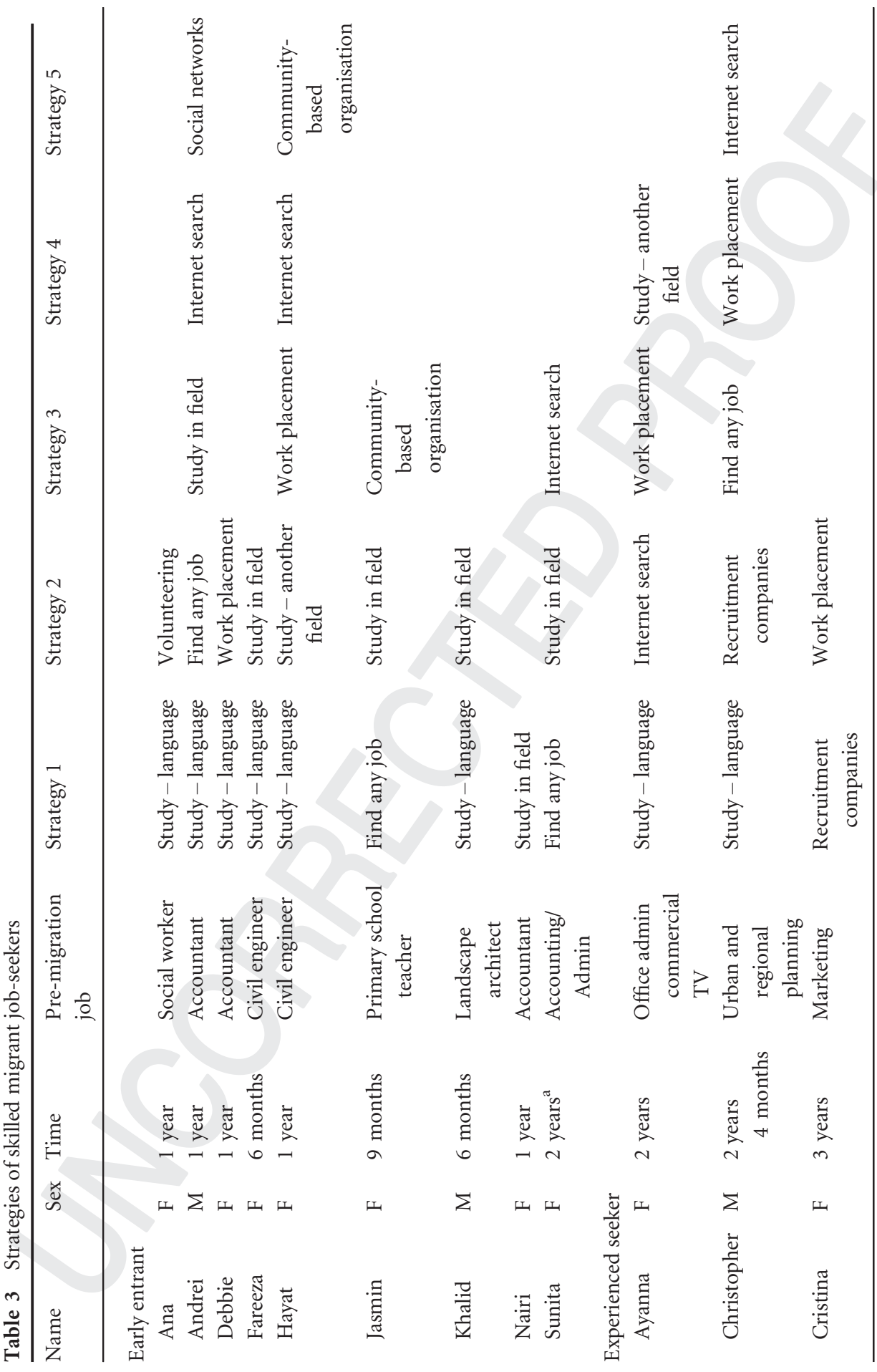


Asia Pacific Journal of Human Resources ••

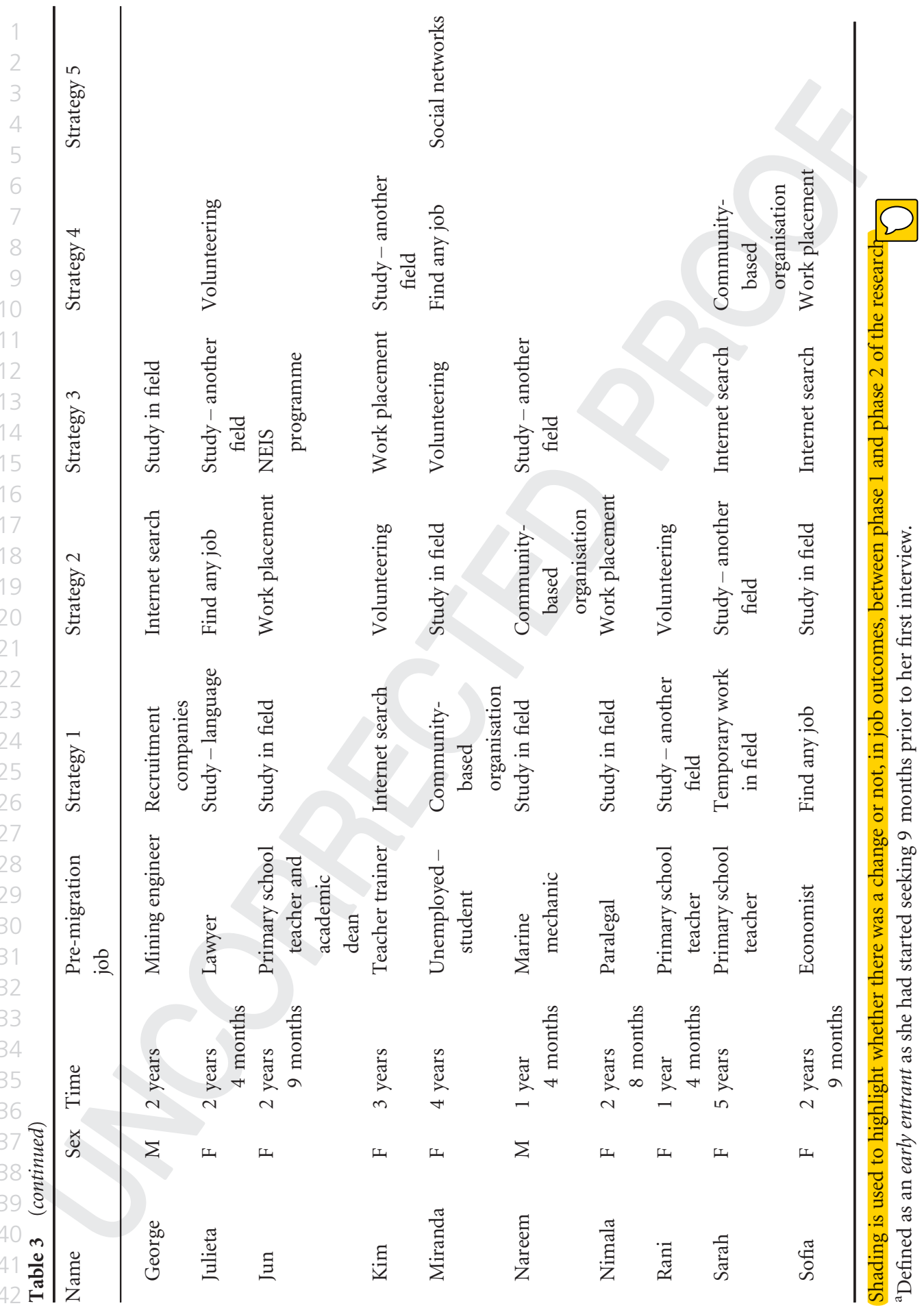


gender norms as expressed by notions such as the male 'breadwinner role' and the gendered role of homemaker (Campbell, Whitehouse and Baxter 2009). In many cases, financial necessity (Raghuram 2008, 2010) and gendered notions about the care of children influenced couples' decision-making. Sunita, for example, tried to find work and was unsuccessful. Her husband was successful, however, so she decided to take a part-time job and study while caring for her young child, as this seemed her only option. Nimala was in the same situation. She wanted to find work to help family finances, and a job in a local supermarket was the only way she could manage employment and the needs of her young family. Women's employment search is not as straightforward as men's. While they face the same barriers in understanding the nuances of the labour market and the perceived discrimination of employers as do men, women with children are more likely to deviate from their career of choice to care for children (Pereira 2012; Phan et al. 2015). In addition, the complexity of the job search can be more constrained if the woman has young children (Ressia 2014).

Despite these challenges, women do want to find work and contribute to family finances but, by necessity, the woman's role is often one of support for the family while her male partner seeks work, at the expense of her own career. She experiences more casualised forms of labour, in low-paid (and highly gendered) occupations (Raijman and Semyonov 1997; Syed and Murray 2009) such as in cleaning, housekeeping and childcare. Nevertheless, these women do try to turn these adverse outcomes into a positive experience, as most were eager to gain local experience and begin to form networks with other workers, as evident in Jasmin's case, and to achieve economic independence in their own right.

The experiences of these women bring into focus the gendering effects of the migration process which inhibits opportunities for seeking work (Kofman 2013). Lack of knowledge about family support services also constrained women. Sunita reported that she did not know that services such as after-school childcare were available to families. Financial costs were another challenge. The cost of childcare often prevented women from seeking employment, limiting them in their choice of work. For example, Hayat, a civil engineer, found that the cost of childcare forced her into taking on the care of her family while her husband pursued further study. This disadvantaged her access to a government-funded specialised training program in her occupation, and she ended up undertaking studies in childcare and finding precarious work within the sector. The current research confirms the ongoing problem faced by migrant women, as highlighted by other scholars who have examined migration and care-giving (Boyle, Feng and Gayle 2009; Cooke 2007; Phan et al. 2015) in this context.

Like men, the women also suffered from difficulties around qualification recognition (Casimiro, Hancock and Northcote 2007; Ressia 2010). However, due to financial and family constraints, their ability to access additional training and courses was restricted. This situation undoubtedly increased stress, and as time progressed the women felt less certain about gaining a job in their field (Liversage 2009). Hayat explained that staying at 
home prevented her from using her knowledge and skills, as she was not keeping up with the changes in her profession:

It's a very difficult life, it's not easy ... I lost all my skills. I'm not sure what happened around me? I can't work on computers because I stay at home ... [and] I didn't know what happened, what's the new thing [technology]?

Feelings of loneliness and isolation also increased due to the loss of established social and familial networks (Boyle, Feng and Gayle 2009; Shinozaki 2014). Cristina said: 'I had moments that I just wanted to run out and go back to my country, to my family, to my friends, to my comfort zone.'

The analysis confirms the significant problems that some NESB migrants experience in finding professional work equivalent to their previous employment. They each experience downward occupational mobility, a phenomenon which is echoed in the findings of much of the migrant employment literature. The study tracked migrants' occupational trajectories through exploring and understanding their job-seeking strategies. The research highlights that the human capital of these migrants is not perfectly transferable; however, they each implemented a range of strategies to try to counteract downward occupational mobility, which is in part explained by assimilation theory (Simón, Ramos and Sanromá 2014). The research indicates that males may be more likely to move upwards, but it is too early to tell whether they will achieve jobs that will improve their occupational mobility, or not. In addition, this research highlights that the mobility trajectories for women are more difficult due to gendering effects, they are more likely to experience worse outcomes (Iredale 2001; Kofman 2013) depending on where they are at in terms of their own life course, and the age of their children. This outcome aligns with the experience of segmented assimilatipn theory, where more permanent forms of occupational downgrading are occur (Simón, Ramos and Sanromá 2014), attributed to the combination of seeking work and managing a young family. Therefore, despite these women arriving with high levels of human capital, the gendering affect in terms of employment outcomes is.

\section{Contribution and limitation of the research}

While it is reported (DIAC 2012a) that skilled migrants in general experience low unemployment, this does not paint the full picture. Such reports do not drill deeply enough in distinguishing outcomes between migrants from English speaking countries and NESB migrants, nor do they consider the issue of downward occupational mobility, which is masked by broad statistics. Further, the CSAM (DIAC 2012b) reports only on primary applicants, who are usually male, and details regarding outcomes for women and skilled migrant couples are lacking. This research has made an empirical contribution through explaining the experiences of women and male migrants, uncovering at a deeper level, the complex issues NESB skilled migrants and their families face.

This research was limited to a small sample of 22 participants and we are unable to make generalisations about the experiences of skilled migrants who do achieve good 
employment outcomes. We suggest that future research considers skilled migrant groups which fall under the sponsored migrant immigration schemes, and those who have recently arrived under humanitarian programs. In addition, it would be interesting for research to consider differences in outcomes in terms of migrants' cultural and ethnic background. While we acknowledge these limitations, the research has also opened up topics requiring further investigation, and suggests that a closer examination be paid to try to find out why employers hesitate to employ skilled migrants in professional jobs. In addition, understanding what supports could be offered to organisations to encourage hiring, and what could improve a migrant woman's prospects of finding work around trying to manage family is important for improving opportunities for this group. This research reveals issues that government, organisations and migrant support networks can consider around immigration policy and migrant employment, with the aim of reducing the underutilisation of human capital. This in turn would be advantageous for the wider economy, and at the same time, provide better employment outcomes for highly skilled migrant women and men.

\section{Conclusion}

Migration has been important to Australia both economically and for population growth, and today is increasingly tied to filling labour market gaps, especially at the 'skilled' end of the spectrum (Markus, Jupp and McDonald 2009). However, the experiences of the NESB skilled migrants in this research, consistent with statistics (ABS 2011), reveal the difficulties of obtaining employment after arrival that is commensurate with their previous position. While amendments to immigration policy have attempted to address issues of unemployment and underemployment, there are still problems in need of attention and resolution. Our article contributes to the literature by providing understandings of the lived experiences of skilled migrants, as they attempt to traverse the labour market in Australia, and the strategies they use to counteract outcomes of downward occupational mobility by increasing their human capital. This article has also shed light on the experiences of female migrants, to fill a gap in the literature identified by others (Cooke 2007; Shinozaki 2014), by providing a more nuanced understanding of the complex issues these skilled migrant job-seekers experience in their search for work. This research has demonstrated that while women and men encounter similar difficulties and use similar strategies in seeking and securing employment, women face additional challenges due to the operation of gender norms associated with family responsibilities.

\section{Acknowledgements}

This research was part of a larger PhD project funded by Griffith University Postgraduate Scholarship.

Susan Ressia (PhD, Griffith Univ) is a lecturer within the Department of Employment Relations and Human Resources at Griffith University, Nathan campus. Her thesis examined the job-search 
experiences of independent non-English speaking background skilled migrants in Australia. Susan's research interests include skilled migrant workers, intersectionality theory, equality and social justice issues.

Glenda Strachan (PhD, UQld) is emeritus professor in the Department of Employment Relations and Human Resources at Griffith University. Her research interests focus on contemporary and historical workplace change especially issues relating to women's working experience. The impact of organisational and national employment policies, especially EEO and diversity management, is a centre of her work. She is co-author of Managing diversity in Australia: theory and practice (2010).

Janis Bailey ( $\mathrm{PhD}$, Murdoch Univ) is an adjunct associate professor with the Department of Employment Relations and Human Resources, Griffith University, Gold Coast, Australia, and is a member of the university's Centre for Work, Organisation and Wellbeing. Her research interests include union strategy and campaigning, vulnerable workers including youth and women, and teaching and learning in business. She is currently working on projects on developing professional identity in ER and HR graduates, and gender equity in universities.

\section{References}

Australian Bureau of Statistics (ABS) (2011) Characteristics of recent migrants, cat. no. 6250.0. ABS, Canberra.

Adkins DE and S Vaisey (2009) Toward a unified stratification theory: structure, genome, and status across human societies. Sociological Theory 27(2), 99-121.

Akresh IR (2008) Occupational trajectories of legal US immigrants: downgrading and recovery. Population and Development Review 34(3), 435-456.

Alcorso C (1991) Non-English speaking background immigrant women in the workforce. Working Papers in Multiculturalism No. 4. Centre for Multicultural Studies, University of Wollongong, Wollongong.

Anderson B (2010) Migration, immigration controls and the fashioning of precarious workers. Work, Employment and Society 24(2), 300-317.

Anthias F (2012) Transnational mobilities, migration research and intersectionality. Nordic Journal of Migration Research 2(2), 102-110.

Australian Bureau of Statistics (ABS) (1996) Year book Australia 1996, cat. no. 1301.0. ABS, Canberra.

Bartram D (2010) The normative foundations of 'policy implications': reflections on international labour migration. Work, Employment and Society 24(2), 355-365.

Bauer TK and KF Zimmermann (1999) Occupational mobility of ethnic migrants. IZA Discussion Paper Series No 58. Institute for the Study of Labor, Bonn, Germany.

Bertone S (2000) Doing it tough: migrants and workplace change. In S Bertone and H Casey (eds) Migrants in the new economy: problems, perspectives and policy, 46-78. Workplace Studies Centre, Melbourne, Vic.. 
Bertone S (2009) Immigration and the labour market in Australia. In J Higley, J Nieuwenhuysen and S Neerup (eds) Nations of immigrants: Australia and the USA compared, 86-99. Edward Elgar, Cheltenham.

Birrell B (2009) Immigration policy in Australia. In J Higley, J Nieuwenhuysenand S Neerup (eds) Nations of immigrants: Australia and the USA compared, 70-85. Edward Elgar, Cheltenham, UK.

Birrell B and E Healy (2008) How are skilled migrants doing? People and Place 16(1), Supplement, $1-19$.

Birrell B and V Rapson (2005) Migration and the accounting profession in Australia. Centre for Urban and Population Research, Monash University, Melbourne.

Böhm A (2004) Theoretical coding: text analysis in grounded theory. In U Flick, E von Kardorffand I Steinke (eds) A companion to qualitative research, 270-275. Sage Publications, London.

Booth A, A Leigh and E Varganova (2010) Does racial and ethnic discrimination vary across minority groups? Evidence from a field experiment. CEPR discussion paper no. DP7913. http:// ssrn.com/abstract=1640989 (accessed 22 Oct 2015).

Boucher A and L Cerna (2014) Current policy trends in skilled immigration policy. International Migration 52(3), 21-25.

Boyle P, Z Feng and V Gayle (2009) A new look at family migration and women's employment status. Journal of Marriage and Family 71(May), 417-431.

Browne I and J Misra (2003) The intersection of gender and race in the labour market. Annual Review of Sociology 29(1), 487-513.

Campbell I, G Whitehouse and J Baxter (2009) Australia: casual employment, part-time employment and the resilience of the male-breadwinner model. In L Vosko, FM MacDonaldand I Campbell (eds) Gender and the contours of precarious employment, 60-77. Taylor and Francis, Abingdon, Oxon.

Casimiro S, P Hancock and J Northcote (2007) Isolation and insecurity: resettlement issues among Muslim refugee women in Perth, Western Australia. Australian Journal of Social Issues 42(1), 5569.

Chambliss DF and RK Schutt (2006) Making sense of the social world: methods of investigation. Pine Forge Press, Thousand Oaks, CA.

Charmaz C (2000) Grounded theory: objectivist and constructivist methods. In NK Denzin and YS Lincoln (eds), Handbook of qualitative research, 2nd edn, 509-536. Sage Publications, Thousand Oaks, CA.

Chiswick BR, YL Lee and PW Miller (2003) Patterns of immigrant occupational attainment in a longitudinal survey. International Migration 41(4), 47-48.

Chiswick BR, YL Lee and PW Miller (2005) A longitudinal analysis of immigrant occupational mobility: a test of the immigrant assimilation hypothesis. International Migration Review 2 (Summer), 332-353.

Clarke A and M Skuterud (2014) Immigrant skill selection and utilization: a comparative analysis of Australia, Canada, and the United State. Office of Population Research, Princeton.

Colic-Peisker V and F Tilbury (2007) Integration into the Australian labour market: the experience of three "visibly different" groups of recently arrived refugees. International Migration 45(1), 5985.

Cooke FL (2007) 'Husband's career first': renegotiating career and family commitment among migrant Chinese academic couples in Britain. Work, Employment and Society 21(1), 47-65. 
Dean L and A Manzoni (2012) International migration as occupational mobility. SOEP Papers on Multidisciplinary Panel Data Research No. 498, DIW, Berlin, Germany.

Department of Immigration and Border Protection (DIBP) (2015a) Migration programme statistics. DIBP, Canberra. https://www.border.gov.au/about/reports-publications/research-statistics/statistics/ live-in-australia/migration-programme (accessed 22 Oct 2015).

Department of Immigration and Border Protection (DIBP) (2015b) Skilled occupation list (SOL). DIBP, Canberra. https://www.border.gov.au/Trav/Work/Work/Skills-assessment-and-assessingauthorities/skilled-occupations-lists/SOL (accessed at 22 October 2015).

Department of Immigration and Citizenship (DIAC) (2012a) Fact sheet 14 - migrant labour market outcomes. DIAC, Canberra, ACT. http://www.immi.gov.au/media/fact-sheets/14labour.htm (accessed 27 Nov 2012).

Department of Immigration and Ctizenship (DIAC) (2012b) How new migrants fare: analysis of the Continuous Survey of Australia's Migrants. DIAC, Canberra. http://www.immi.gov.au/media/ publications/research/_pdf/csam-results-2010.pdf. (accessed 14 Oct 2012).

Docquier F, BL Lowell and A Marfouk (2009) A gendered assessment of highly skilled emigration. Population and Development Review 35(2), 297-321.

Fang T, M Novicevic and J Zikic (2009) Career success of immigrant professionals: stock and flow of their career capital. International Journal of Manpower 30(5), 472-488.

Fontana A and J Frey (2000) The interview form structured questions to negotiated text. In Denzin NK, Lincoln YS (eds) Handbook of qualitative research, 2nd edn, 645-672. Sage Publications, Thousand Oaks, CA.

Fossland T (2013) Negotiating future careers: a relational perspective on skilled migrants' labour market participation. Journal of Management Development 32(2), 193-203.

Glaesser J and B Cooper (2014) Using rational action theory and Bourdieu's habitus theory together to account for educational decision-making in England and Germany. Sociology 48(3), 463-481.

Goldthorpe JH and C Payne (1986) On the class mobility of women: results from different approaches to the analysis of recent British data. Sociology 20(4), 531-555.

Goldthorpe JH, C Payne and C Llewellyn (1978) Trends in class mobility. Sociology 12(3), 441-468.

Groutsis D and PC Arnold (2012) Tracking the career directions and experiences of migrant elites: the case of South-African-trained medical professionals in the Australian labour market. Health Sociology Review 21(3), 332-342.

Hawthorne L (2005) 'Picking winners': the recent transformation of Australia's skilled migration policy. International Migration Review 39(3), 663-696.

Hibbins R (2005) Migration and gender identity among Chinese skilled male migrants to Australia. Geoforum 36(2), 167-180.

Ho C (2006) Migration as feminisation? Chinese women's experiences of work and family in Australia. Journal of Ethics and Migration Studies 32(3), 497-514.

Ho C and C Alcorso (2004) Migrants and employment: challenging the success story. Journal of Sociology 40(3), 237-259.

Iredale R (2001) The migration of professionals: theories and typologies. International Migration 39 (5), 7-26.

Iredale R (2005) Gender, immigration policies and accreditation: valuing the skills of professional women migrants. Geoforum 36(2), 155-166.

Jackson M (2009) Disadvantaged through discrimination? The role of employers in social stratification. The British Journal of Sociology 60(4), 669-692. 
Kofman E (2013) Towards a gendered evaluation of (highly) skilled immigration policies in Europe. International Migration 52(3), 116-128.

Kofman E and P Raghuram (2006) Gender and global labour migrations: incorporating skilled workers. Antipode 38(2), 282-303.

Kõu A, L van Wissen, J van Dijk and A Bailey (2015) A life course approach to high-skilled migration: lived experiences of Indians in the Netherlands. Journal of Ethnic and Migration Studies 41(10), 1644-1663.

Liversage A (2009) Vital conjectures, shifting horizons: high-skilled female immigrants looking for work. Work, Employment and Society 23(1), 120-141.

Long J and J Ferrie (2003) Labour mobility. In Mokyr J (ed.) Oxford encyclopedia of economic history. Oxford University Press, New York.

Long J and J Ferrie (2013) Intergenerational occupational mobility in Great Britain and the United States since 1850. American Economic Review 103(4), 1109-1137.

Mahuteau S and PN Junankar (2008) Do migrants get good jobs in Australia? The role of ethnic networks in job search. The Economic Society of Australia 84(S1), S115-S130.

Markus A, J Jupp and P McDonald (2009) Australia's immigration revolution. Allen and Unwin, Crows Nest, NSW.

McAllister I (1995) Occupational mobility among immigrants: the impact on economic success in Australia. International Migration Review 32(2), 441-468.

McDowell L (2008) Thinking through work: complex inequalities, constructions of difference and trans-national migrants. Progress in Human Geography 32(4), 491-507.

Misko J (2012) The role of qualifications in foreign labour mobility in Australia. National Centre for Vocational Education Research, Adelaide, SA.

Papademetriou D and M Sumption (2011) Rethinking points systems and employer-selected immigration. Migration Policy Institute, Washington, DC.

Pereira S (2012) Immigrant workers' (im)mobilities and their re-emigration strategies. Employee Relations 34(6), 642-657.

Phan MB, R Banerjee, L Deacon and L Taraky. 2015. Family dynamics and the integration of professional immigrants in Canada. Journal of Ethnic and Migration Studies 41(13), 2061-2080

QSR International Pty Ltd (2010) NVivo 9. Melbourne, Vic.

Raghuram P (2008) Migrant women in male-dominated sectors of the labour market: a research agenda. Population, Space and Place 14(1), 43-57.

Raijman R and M Semyonov (1997) Gender, ethnicity, and immigration: double disadvantage and triple disadvantage among recent immigrant women in the Israeli labor market. Gender and Society 11(1), 108-125.

Remennick L (2005) Immigration, gender, and psychosocial adjustment: a study of 150 immigrant couples in Israel. Sex Roles 53(11/12), 847-863.

Ressia S (2014) Skilled migrant women and men seeking employment: expectations, experiences and outcomes. Unpublished PhD Thesis, Griffith University.

Ressia S (2010) Starting from scratch: skilled dual career migrant couples and their search for employment in South East Queensland. International Journal of Employment Studies 18(1), 6388.

Rooth DO and J Ekberg (2006) Occupational mobility for immigrants in Sweden. International Migration 44(2), 57-77. 
Rynderman J and C Flynn (2014) 'We didn't bring the treasure of Pharaoh': skilled migrants' experiences of employment seeking and settling in Australia. International Social Work 59(2), $268-283$

Shan H (2013) Skill as a relational construct: hiring practices from the standpoint of Chinese immigrant engineers in Canada. Work, Employment and Society 27(6), 915-931.

Shinozaki K (2014) Career strategies and spatial mobility among skilled migrants in Germany: the role of gender in the work-family interaction. Tijdschrift voor Economische en Sociale Geografie 105(5), 526-541.

Simón H, R Ramos and E Sanromá (2014) Immigrant occupational mobility: longitudinal evidence from Spain. European Journal of Population 30, 223-255.

Smith K (2007) Operationalizing Max Weber's probability concept of class situation: the concept of social class. The British Journal of Sociology 58(1), 87-104.

Sørensen AB (1991) On the usefulness of class analysis in research on social mobility and socioeconomic inequality. Acta Sociologica 34, 71-87.

Syed J (2008) Employment prospects for skilled migrants: a relational perspective. Human Resource Management Review 18(1), 28-45.

Syed J and P Murray (2009) Combating the English language deficit: the labour market experiences of migrant woman in Australia. Human Resource Management Journal 19(4), 413-432.

Vianello FA (2014) Ukrainian migrant workers in Italy: coping with and reacting to downward mobility. Central and Eastern European Migration Review 3(1), 85-98.

Walsh J (2008) Navigating globalization: immigration policy in Canada and Australia, 1945-2007. Sociological Forum 23(4), 786-813.

Wright CF (2012) Immigration policy and market institutions in liberal market economies. Industrial Relations Journal 43(2), 110-136. 